\title{
The political history of Classical Hollywood: moguls, liberals and radicals in the
}

\section{$\underline{1930 s}$}

\author{
Professor Mark Wheeler, \\ London Metropolitan University
}

\section{Introduction}

Hollywood's relationship with the political elite in the Depression reflected the trends which defined the USA's affairs in the interwar years. For the moguls mixing with the powerful indicated their acceptance by America's elites who had scorned them as vulgar hucksters due to their Jewish and show business backgrounds. They could achieve social recognition by demonstrating a commitment to conservative principles and supported the Republican Party.

However, MGM's Louis B. Mayer held deep right-wing convictions and became the vice-chairman of the Southern Californian Republican Party. He formed alliances with President Herbert Hoover and the right-wing press magnate William Randolph Hearst. Along with Hearst, Will Hays and an array of Californian business forces, 'Louie Be' and MGM's Production Chief Irving Thalberg led a propaganda campaign against Upton Sinclair's End Poverty in California (EPIC) gubernatorial election crusade in 1934. This form of 'mogul politics' was characterized by the instincts of its authors: hardness, shrewdness, autocracy and coercion. 
In response to the mogul's mercurial values, the Hollywood community pursued a significant degree of liberal and populist political activism, along with a growing radicalism among writers, directors and stars. For instance, James Cagney and Charlie Chaplin supported Sinclair's EPIC campaign by attending meetings and collecting monies. Their actions reflected the economic, social and political conditions of the era, notably the collapse of US capitalism with the Great Depression, the New Deal, the establishment of trade unions, and the emigration of European political refugees due to Nazism.

Therefore, President Franklin D. Roosevelt (FDR) courted Warner Brothers to make films supporting New Deal values and appointed Jack L. Warner as the Los Angeles Chairman of the National Recovery Administration (NRA). Elsewhere, stars and writers such as Edward G. Robinson, and Dudley Nichols lent themselves to liberal, international causes. Some activists became attracted to the Hollywood Communist Party, which was a small, but potent, force in 1930s. This tide of Hollywood liberalism and radicalism was enhanced by the migration of New York based writers and stage actors who, in the wake of sound films, had resettled on the West Coast.

This essay will outline the development of the moguls' politics and how they courted the 'great and good' in American civil life. It will demonstrate how the social changes instituted by the New Deal provided the context through which the Hollywood workforce became politically conscious. Finally, it will discuss how the techniques employed by the moguls in EPIC campaign defined the political divide between left and right which emerged in Hollywood in the 1930s and would provide the context for the anti-Communist blacklist of the 1940s and 1950s. 


\section{$\underline{\text { The Moguls' politics }}$}

The movie moguls (the Warner Brothers, Louis B. Mayer, Joseph and Nicholas Schenck, Adolph Zukor, Harry Cohn, Carl Laemmle, Samuel Goldwyn), with two exceptions (Darryl Zanuck, Walt Disney), shared a common Jewish immigrant heritage. ${ }^{1}$ They embodied the American dream, rising from the teaming immigrant urban ghettos to make their fortunes in the new medium of the cinema. Yet, as they had sampled the extremes of poverty and wealth, they preserved their fortunes, downplayed their Jewishness and assimilated themselves into mainstream American society. ${ }^{2}$

While they took pride in their accumulation of riches, the moguls remained aware of the anti-Semitism which prevailed from ingrained White Anglo Saxon Protestant (WASP) prejudice. ${ }^{3}$ They were barred from Los Angeles' exclusive country clubs and oldest business groups. In spite of their battles with one another their real enemies were 'the ... goyim of Wall Street who were constantly plotting to take over their studios.' ${ }^{4}$

${ }^{1}$ Budd Schulberg, Moving Pictures: Memories of a Hollywood Prince, (New York: Souvenir Press, 1981).

${ }^{2}$ Neal Gabler, An Empire of Their Own: How the Jews Invented Hollywood. (New York: Doubleday, 1985).

${ }^{3}$ Colin Shindler, Hollywood in Crisis: Cinema and American Society 1929-1939, (London and New York: Routledge, 1996), pp. 61-2.

${ }^{4}$ Ibid., p. 63. 
Subsequently, they remained conscious of their need to achieve respectability in America's highest circles of power. ${ }^{5}$

Often, the moguls were Republican not because of any deeply held conviction but as most wealthy Americans voted for the Grand Old Party (GOP). By showing their attachment to 'sound' conservative principles they could withstand any potential antiSemitic attack. Their values were determined by self-interest and, in the case of Jack Warner, if they acquired the requisite status they would vote Democrat. ${ }^{6}$ The exception was the Vice-President and General Manager of MGM --- Louis B. Mayer.

\section{Louis B. Mayer: The Proud Pigeon meets his political mates}

Mayer was a tremendous egoist, who not only ran the industry's most glamorous studio, but wanted acceptance from the powerful elite who owned the country. As an outsider, he embraced the respectable classes and spent as little time as possible with fellow filmmakers. Mayer championed conservative values based on the sanctity of order, authority, patriotism, clean living, small-town solidarity and family. To realise his political ambitions Mayer served in Republican Calvin Coolidge's 1924 Presidential campaign as an enthusiastic, but lowly, neophyte wherein he established a strong linkage with Ida R. Koverman who was Herbert Hoover's chief political operative in California. She would become Mayer's personal secretary, thereby giving him access to the rising political star. Moreover, as the secretary of the Los Angeles Republican Party Central

\footnotetext{
${ }^{5}$ Ronald Brownstein, The Power and the Glitter: The Hollywood-Washington Connection, (New York: Vintage Press, 1990), p. 26.

${ }^{6}$ Shindler, Hollywood in Crisis, p. 63.
} 
Committee, Koverman gave him an entrée into the Southern Californian branch of the GOP.

To fund Hoover's Presidential ambitions, Mayer required MGM's studio workers to contribute to the candidates' campaign coffers. Moreover, as the Californian delegate to the 1928 Republican Convention he persuaded the newspaper baron William Randolph Hearst to support Hoover. As a kingmaker, Mayer drew upon a relationship with Hearst which was founded on mutual self-interest wherein Mayer called Hearst 'chief' and Hearst named him 'son.' After Hoover's successful Presidential election, he swelled with pride when he was asked to be the first overnight guest to stay at the White House and as Koverman noted to Lawrence Richey, an aide to the President-elect:

Re: Louis B Mayer. Do you remember our talk about making a gesture? Why could we not include a trip to Florida [where Hoover was vacationing] for a couple of days? This is another small boy --- new at the game and used to a great deal of attention. I know he would strut around like a proud pigeon. ${ }^{7}$

The collapse of the Hoover administration and the 1932 Presidential Election Unfortunately for Mayer, Hoover's inability to react to the Great Depression led to a collapse in his administration. Throughout, Mayer remained a committed supporter and in 1931 presented Hoover with a national survey of business leaders' ideas for reinvigorating the economy. However, his political influence was limited when he tried to rally a disillusioned Hearst to the Republican cause in the 1932 Presidential election. The

${ }^{7}$ Brownstein, The Power and the Glitter, p. 21. 
press magnate, sensing the change in national mood, supported Roosevelt and cut his ties with Mayer. Similarly, Hoover had little interest in meeting Hearst and the mogul became the unwitting instrument in the breakdown of relations between the pair.

Nonetheless, Mayer made radio broadcasts supporting the moribund Hoover, who spent his time locked away in the White House. He tried to lift the prevailing tide of gloom hanging over the 1932 GOP convention by stage-managing a half-hour proHoover rally on its final day, but could not remove the sense of foreboding. Undeterred, Mayer informed the press that the economy was about to turn and Hoover would win a triumphant re-election. For his efforts, Mayer was appointed as the chairman of the Republican State Central Committee in September 1932 and made ponderous speeches which 'cemented his pre-eminent political role in Hollywood and made him an even more visible public figure.'8

Yet, while Mayer rallied against Franklin D. Roosevelt, he watched helplessly as his friend was swept out of the White House. Although he remained Hollywood's most politically visible mogul, he never recovered from Hoover's defeat. In 1933 he accepted an invitation to meet Roosevelt in the Oval Office wherein he produced a clock from his coat and placed it on the Chief Executive's desk. Roosevelt inquired, 'What's that for, Mr. Mayer?' Mayer replied, 'Pardon me Mr. President. I heard you have the ability to have a man in your hip pocket after eighteen minutes.' After Roosevelt chatted to the

\footnotetext{
${ }^{8}$ Ibid., p.39.
} 
mogul for seventeen minutes he was surprised to see Mayer abruptly grab his clock and exit the room $!^{9}$

\section{FDR and Warner Brothers: Good Citizenship and Good Pictures}

Despite Mayer's antipathy for Roosevelt, throughout the 1932 Presidential campaign he received the backing of film stars including Will Rogers, Gloria Stuart and Katherine Hepburn. Moreover, FDR reached out to the rest of Hollywood as he understood the power of cinema and made alliances throughout the motion picture industry.

For Warner Brothers (a studio that prided itself on 'Good Citizenship and Good Pictures') FDR's patronage enhanced its status as an industry leader. Throughout its 1930s films it included political and social issues which reflected both the strengths (reform, social welfare) and the ambiguities of the New Deal: confusion, compromise and vagueness.

The relationship between the studio and the administration reflected the changing political convictions of the Head of Production Jack Warner and Chief Executive Harry Warner, who had transferred their allegiance from Hoover to Roosevelt during the 1932 Presidential campaign. In this respect, Hearst was instrumental as he sought film executives, in preference to Mayer, to be induced into supporting FDR. To complete his conversion, Jack Warner was summoned to New York by his brother Harry (who acted as Roosevelt's point man in Hollywood) to be presented to Democrat leaders Jim Farley,

9 Stephen Schochet, 'Tales of Hollywood and Politics', Hollywood Stories, 2010.

Accessed on May 2 2013, http://www.hollywoodstories.com/pages/hollywood/h22.html. 
Joseph P. Kennedy, Al Smith, and J.J. Raskob who argued, 'There is revolution in the air and we need a change'. ${ }^{10}$

Therefore, Warner organised a spectacular rally at the Los Angeles Memorial Coliseum to which he and Production Chief Darryl F. Zanuck invited almost every major star in the industry except those who Mayer barred from attending. Sitting in a flagdraped box, the future President was courted by the Hollywood royalty who were as much in thrall of him as he was of them. As a reward, Roosevelt appointed Jack Warner as the Los Angeles Chairman of the National Recovery Administration (NRA).

Roosevelt, however, was in no way star struck by Hollywood. He used the studios to enhance his campaign and political image. He shrewdly kept friendly relations with Will Hays, despite the movie czar's background as a Republican politician. In addition Zanuck became a constant visitor to the White House, and when Thalberg died FDR sent condolences to his widow Norma Shearer. If anything, it remained the case that Hollywood continued to be in awe of the President. He understood how much the moguls sought social acceptance, and happily provided them with an autographed photo or an invitation to dinner at the White House. Harry Warner remained a New Deal advocate and ensured the studio's films conformed to a mantra of 'Educate, Entertain and Enlighten.' ${ }^{11}$ And his brother Jack continued to enthuse, 'I found him a vital and

\footnotetext{
${ }^{10}$ Jack L. Warner, with Dean Jennings, My First Hundred Years in Hollywood, (New York: Random House, 1964), pp. 215-6.

${ }^{11}$ Nancy Snow, 'Confessions of a Hollywood Propagandist: Harry Warner, FDR and Celluloid Persuasion,' in Johanna Blakley et.al., Warners' War: Politics, Popular Culture
} 
enormously magnetic man and ... we began a friendship that endured to the day he died. $^{12}$

\section{Hollywood Liberals and Radicals}

While Roosevelt was not the first President to associate with entertainment community, he was the first to invite film stars to luncheons and birthday balls to enhance his standing with the electorate. In this manner he sustained relationships with stars who, feeling suitably honoured, would lend themselves to election campaigns and public works schemes. ${ }^{13}$ Most especially, Hollywood's liberals were welcomed to the White House and the President formed close relations with Melvyn Douglas and his wife Helen Gahagan Douglas and Will Rogers as he realised, 'Combining forces with the big names of screen could only enhance a politician's standing. ' 14

The Hollywood Democratic Committee and campaign support

Melvyn Douglas campaigned for Roosevelt, became a leader in the state Democratic Party and was the first actor to serve as a delegate to the national Democratic Convention. Under his tutelage Gahagan transferred her acting skills into political ambitions and

and Propaganda in Wartime Hollywood, (Los Angeles: Norman Lear Center, 2003), p.

69.

${ }^{12}$ Brownstein, The Power and the Glitter, p. 93.

${ }^{13}$ Alan Schroeder, Celebrity in Chief: How Show Business took over the White House, (Boulder Colarado and Oxford: Westview Press, 2004), p.10-16.

${ }^{14}$ Ibid., p. 18. 
became an advocate for the rural poor in California. She forged a close relationship with Eleanor Roosevelt and would outdo her husband in seeking electoral office (she became a Democratic Congresswoman and candidate in the 1950 California Senatorial contest against Republican Richard Nixon). ${ }^{15}$

Roosevelt's liberalism appealed to those Hollywood activists who were concerned about injustice at home and the encroachment of Fascism abroad. The comedian Will Rogers, from 1933 until his untimely death in 1935, was deemed to be the 'Number One New Dealer' through his advancement of FDR's Keynesian policies on his popular radio show:

On the radio he mixed the humorous advice on health and good food with words of support for 'Franklin's' effort to pass social security, to levy high income taxes on the rich, and to provide jobs through public works. In the world of foreign affairs, Rogers was also one of the first to recognise the rise of fascist threats. ${ }^{16}$

A more strategic form of politicization occurred when the Hollywood Democratic Committee (HDC) was formed to mobilise support for the President throughout his election campaigns in 1936, 1940 and 1944. Therefore, film stars such as Humphrey

${ }^{15}$ Greg Mitchell, Tricky Dick and the Pink Lady: Richard Nixon vs. Helen Gahagan Douglas --- Sexual Politics and the Red Scare, 1950, (New York: Random House, 1998), pp. 21-2.

${ }^{16}$ Lary May, The Big Tomorrow: Hollywood and the Politics of the American Way, (Chicago and London: University of Chicago Press, 2000), p.45. 
Bogart, Edward G. Robinson, John Garfield and Judy Garland accompanied the President on campaign rallies and whistle-stop tours across the country. As Life Magazine (1883onwards) commented, 'Since the New Deal's salad days, Tin Pan Alley has almost been as staunchly Democratic as Tammany Hall. Broadway and Hollywood have consistently expended most of their political enthusiasm on Franklin D. Roosevelt. ${ }^{17}$

\section{The Gothamization of Tinseltown}

This tide of liberalism reflected the migration of many New York based writers and stage actors who in the wake of sound had resettled on the West Coast. For Broadway stars the lure of salaries offered in Hollywood was irresistible. Steven Ross has commented that 'these men and women tended to be more educated, cultured and politically engaged than those who had spent their entire career in ... 'the low brow world of motion pictures. ${ }^{18}$ As sound films required good dialogue, the studios sought out Broadway based playwrights, novelists and short-story writers. This cohort included: George S. Kaufman, F. Scott Fitzgerald, Nathaniel West, Donald Ogden Stewart, Sidney Buchman, Edna Ferber, Moss Hart, Marc Connelly, Sidney Howard and Lillian Hellman. Such writers

\footnotetext{
${ }^{17}$ × Political Potpourri: Broadway and Hollywood contribute skits and slapstick to enliven Democratic campaign.' Life Magazine, October 23 1944, pp. 32-3. Accessed February 26, 2013, http://books.google.co.uk/books: life.

${ }^{18}$ Ross, Hollywood Left and Right, p. 95.
} 
had emerged from New York literary, liberal and socialist backgrounds, often being trained in the vernacular of Jewish street debates. ${ }^{19}$

While some writers readily took the money, others complained about the philistine-like tendencies of executives. For instance, Thalberg saw writers as factory employees who clocked in, worked for five and half-days, and produced eleven pages of script per week. ${ }^{20}$ Such conditions led to the formation of the Screen Writers Guild (SWG) in 1933 and the politicization of many writers. ${ }^{21}$ Initially, the writers' education occurred in a Southern Californian landscape unencumbered by political machines, strong forms of partisanship or trade unions. Yet, when they became more politically experienced they were cannier operators who adopted clearly drawn ideological positions. Several activists were attracted to the Hollywood Communist Party, which was a small, but potent, force in 1930s led by screenwriter John Howard Lawson. More generally, such politicization was evident within the struggles to gain recognition for the screen guilds and in the taking up of anti-Fascism which proved to be a rallying call for liberals and radicals alike.

${ }^{19}$ Larry Ceplair, and Steven Englund, The Inquisition in Hollywood: Politics in the Film Community, 1930-60, Urbana and Chicago: University of Illinois Press, p. 85.

20 Shindler, Hollywood in Crisis, p. 54. It was also suggested that when Mayer cut MGM wages by fifty percent in the Hollywood financial crisis of 1933 that he created more Communists than Karl Marx.

21 Gerald Horne, Class Struggles in Hollywood 1930-1950: Moguls, Mobsters, Stars, Reds and Trade Unionists, (Austin: University of Texas Press, 2001). 
The Anti-Nazi League, MPAC and the Popular Front

The Anti-Nazi League for Defence of American Democracy (ANL) included many liberals. Within their number, there were writers and directors such as Philip Dunne and John Cromwell, and film stars and actors including Gloria Stuart, Frederic March, his wife Florence Eldridge, and Melvyn and Helen Gahagan Douglas. As more Jewish refugees from Europe came to Hollywood, with tales of the Nationalists atrocities in the Spanish Civil War and the Nazi's anti-Semitism, the League was accompanied by other anti-Fascist causes. These included the Motion Picture Artists Committee to Aid a Republican Spain (MPAC), whose membership peaked at 15,000, and the left dominated Popular Front groups. ${ }^{22}$

The refugees were welcomed into the Hollywood community and the industry became 'awash with "experts" in the nature, forms and evils of fascism. ${ }^{23}$ Indeed, many liberals who had visited Europe were appalled by the rise of Mussolini, Hitler, and Franco and the complicity of Britain, France and the US. Consequently, they mobilised to support and provide financial aid to the Republican cause in Spain. For the Front's leaders the recruitment of celebrities allowed them to transmit an anti-Fascist agenda throughout the nation's media. Concurrently, the ANL mounted petitions, held public meetings, broadcasted a weekly radio programme, published a biweekly paper and

${ }^{22}$ Greg R. Rabidoux, Hollywood Politicos': Then and Now, (Lanham: University Press of America, 2009), p. 39.

${ }^{23}$ Ceplair and Englund, The Inquisition in Hollywood, p. 97. 
picketed the German Embassy. In 1939 it sponsored several labour and Quarantine Hitler rallies while co-ordinating with the MPAC a 'Save Spain' rally at the Hollywood Legion stadium:

The entertainment world closed ranks solidly ... with anti-Nazi forces to form an international bloc of artists and intellectuals against fascism ... Most big Hollywood parties [would include a] guest of honour who might be Andre Malraux or Ernest Hemingway, here to raise money to send ambulances to Loyalist Spain. ${ }^{24}$

The MPAC raised funds for the Republican cause by staging 'Sticks and Stones' a political cabaret which attacked those 'domestic gnats' that mobilised against the Popular Front and 'foreign soldier ants' who swarmed against the world's democracies. The skits criticised reactionaries like Martin Dies (the first Chairman of the House Committee on Un-American Activities (HUAC)). An offshoot of the MPAC, the Freedom of the Screen Committee sponsored the Communist writer Lawson's 1938 film about the Spanish Civil War, Blockade. And Lawson and other Hollywood party members would grow in importance within the circles of anti-Fascist activism.

\footnotetext{
${ }^{24}$ Philip Dunne, Take Two: A Life in Movies and Politics (Updated version), (New York: Limelight Edition, 1992), p. 115.
} 
The Hollywood Communist Party and the Popular Front

In the 1930s the Hollywood Communist party had become a lightning rod for those "tender comrades" who believed Communism could answer the ills of American capitalism and Fascism. ${ }^{25}$ Its membership included Lawson, Dalton Trumbo, Ring Lardner Junior, Alvah Bessie, Abraham Polonsky, Marsha Hunt, Lionel Stander, Budd Schulberg, Paul and Sylvia Jarrico, Donald Ogden Stewart and Jules Dassin. Hollywood Communists were primarily committed to the party's stands rather than to its ideology, structure or hierarchy. Subsequently, the US Communist Party (CPUSA) articulated the concerns of many in Hollywood regarding rights, decency, justice and equality. ${ }^{26}$

In turn, Hollywood's Popular Front organizations comprised from a growing number of Communists. For a while, the bonds between CPUSA members and liberal supporters remained reasonably strong as revolutionary rhetoric was played down. Yet, while liberals like Douglas and Dunne agreed with anti-Fascist sentiments they did not intend to bring down capitalism. Conversely, Hollywood Communists saw the Front as a means through which to recruit liberals to the party. ${ }^{27}$ The final break occurred in 1939 when Stalin signed the non-aggression pact with Hitler. It led to the collapse of the Anti-

\footnotetext{
${ }^{25}$ Patrick McGilligan and Paul Buhle, Tender Comrades: A Backstory of the Hollywood Blacklist, (New York: St. Martin's Griffin 1997), p. xv.

${ }^{26}$ Donald Ogden Stewart, American Film Institute Oral History Programme. (December 1971), p. 94.

${ }^{27}$ Brownstein, The Power and the Glitter, p. 67.
} 
Nazi League, MPAC and the affiliated groups within the Popular Front. ${ }^{28}$ The pact would further lead to significant divisions within the Motion Picture Democratic Committee (MPDC).

The Motion Picture Democratic Committee: the Stalin-Hitler pact and the collapse of liberal and Communist relations

Philip Dunne and Melvyn Douglas had formed the MPDC and remained the unofficial leaders of its liberal faction. While both remained staunch Democrats, as pragmatic liberals they had worked with the Communists as the party had tied itself to the causes of social justice and anti-Fascism. This opinion changed overnight with the signing of pact and the Nazi invasion of Poland. The unity in the MPDC was shattered as it became apparent the liberal and Communist factions in the Executive Board stood against each other. Dunne and Douglas believed the Soviet Union's withdrawal from anti-Fascism would lead to the disintegration of the cause across Europe. Conversely, Hollywood Communists loyally pursued the CPUSA's line which maintained World War Two was nothing more than an imperialist exercise between Fascists and illegitimate 'democracies'. ${ }^{29}$

The MPDC's liberals had no patience for this volte-face and were indignant when the Communist members of the board rigged a vote of 10 votes to 7 to ensure the committee would reverse its anti-Fascist stance. Dunne and Douglas, feeling the Communist organisers had been permanently discredited, forced the issue in the autumn

${ }^{28}$ Ceplair and Englund, The Inquisition in Hollywood, p. 135.

${ }^{29}$ McGilligan and Buhle, Tender Comrades, pp. 617-8. 
of 1939 when they drafted a resolution to be presented to the MPDC Executive to align it with Roosevelt's stance on international diplomacy. However, the resolution was poorly received by the board at a meeting on 19 December 1939 as several Communists argued an alliance with Roosevelt would push the MPDC into the hands of the far right.

To counter this position, the Dunne-Douglas faction maintained the CPUSA had already 'objectively aligned' the MPDC to the right by taking on Stalin's isolationist position. In the event, the board's members were swayed by the Communists and rejected the resolution. Despite Dunne and Douglas' submission of a revised resolution, the MPDC continued to reject any affiliation with the Democrats. Eventually, this led to a showdown meeting with Dunne which was attended by 300 people at the Hollywood Women's Club wherein the resolution was thrown out. By then Douglas had already resigned from the MPDC and the Anti-Nazi League in which he had been subject to person abuse. In the light of Dunne's defeat, the disillusioned liberals resigned en masse from the MPDC and there was a complete disintegration of the fragile unity which had previously existed between them and the Communists. Throughout 1940, Douglas shamed Communist leaders in several speeches concerning the collapse of the Popular Front. He concluded Communists should be barred from any future liberal organization:

It was a problem of trustworthiness ... not of their being Communists per se. Their long-term goals were not mine, and they were using my goals as expedients to achieve goals in which I did not believe. They were obstructionists. ${ }^{30}$

\footnotetext{
${ }^{30}$ Douglas quoted from Ceplair and Englund, The Inquisition in Hollywood, p. 149.
} 


\section{The conservative backlash and the Dies Committee}

In spite of the liberals' position on social and international affairs or Roosevelt's New Deal vision there was sizable conservative presence in 1930s Hollywood. The Production Code Association (PCA) head Joseph Breen undermined the Hollywood ANL, which he believed was 'a conspiracy of left-leaning screenwriters ... that strove to capture the screen of the United States for Communistic propaganda purposes. ${ }^{31}$ Consequently, while Melvyn Douglas was attacking Communists, he suffered from the indignity of a Photoplay interview entitled 'Is Melvyn Douglas a Communist?' The right targeted Douglas as he had been appointed by Eleanor Roosevelt to head the Arts Council of the Office Civilian Defence's Voluntary Participation Branch. He was accused of enjoying the 'frills' of the post (a sinecure of \$8000), displaying Communist tendencies and conforming to his Jewish heritage. ${ }^{32}$

For anti-New Dealer reactionaries the fact that HUAC, chaired by a right-wing Texan Congressman Martin Dies, had cleared Douglas was irrelevant. The Dies Committee had been established in 1938 to root out anti-Americanism within civil society, but it was mainly noted for the anti-Communist and anti-New Deal bias of its chairman and membership which included J. Parnell Thomas. Dies believed it was his duty to root out Communist subversion and this prejudice meant that Dies had closed the Roosevelt backed Federal Theatre and Writers' Project. Similarly, he placed Hollywood's trade unions and its liberal anti-Fascist organizations under HUAC's microscope.

\footnotetext{
${ }^{31}$ J. Hoberman, and Jeffery Shandler, Entertaining America: Jews, Movies and Broadcasting, (Princetown: Princetown University Press, 2003), pp. 61-62. ${ }^{32}$ Ibid., p. 150.
} 
For example, Dunne, along with Cagney, March and Humphrey Bogart, was investigated by HUAC when he was placed on the Californian State Senator Jack Tenney's (the chair of the state version of HUAC) 'Red' activities list. It was Dies intention to declare that this group of liberals were Communists. Therefore, Dunne contacted a Congressional ally Maury Maverick who advised him that the group should accommodate Dies by appearing at a hearing to refute the charge and to shake his hand for the awaiting newspaper photographers. This would enable the HUAC chair to 'clear' them as 'good' American citizens, thereby achieving the good headlines he desired.

Yet the committee fell into disrepute in 1938-40 when the publicity seeking Dies overreached himself by including the child-star Shirley Temple on a list with Cagney, Clark Gable and Robert Taylor of Hollywood actors who had sent greetings to a French Newspaper, Ce Soir, which was owned by the Communist Party. So while the head of Paramount Studios Y. Frank Freeman informed Dies that Hollywood would cooperate with him, he also told him the industry's 32,000 workers would not 'yield to anyone in their true Americanism. ${ }^{33}$

However, Dies anti-Semitism in which he conflated Jewishness with Communism in his vocal attacks on the Hollywood Anti-Nazi League, served as a forewarning of what was to come. The 1930s version of HUAC indicated how Hollywood would have to continually demonstrate its 'American' values to the US political elite. On either side of the political divide there was the realization the industry's tremendous popularity, tied together with its Jewish complexion, opened it up to WASP

\footnotetext{
${ }^{33}$ Steven Alan Carr, Hollywood and Anti-Semitism: A Cultural History up to World War II, (Cambridge: Cambridge University Press 2001), p. 172.
} 
suspicion. For the moguls, such anti-Semitism was a contributory factor to their reactionary defence of 'American' values against Upton Sinclair's 1934 campaign to become the Democratic Governor of California.

\section{Upton Sinclair and the 1934 EPIC campaign}

Sinclair's End Poverty in California (EPIC) campaign made conspicuous the divisions existing in Hollywood's political affairs. He was known as the muckraking author of The Jungle (1906), an expose of Chicago's meatpacking industry, and had campaigned against the vested interests that had corrupted the US's political economy. A native Californian, Sinclair was an active Socialist whose plans to raise corporation taxes led to the moguls perceiving him to be a threat to their interests, most especially in the aftermath of the 1933 financial crisis in which Paramount and MGM had almost been bankrupted. For Hollywood liberals and radicals, the EPIC campaign provided an opportunity through which they could support social reforms.

In June 1934 Will Rogers announced Sinclair intended to be elected as the Democratic candidate for the Californian Governorship. Six weeks later, he swept the party's primary on 28 August 1934 to run on the EPIC platform (accompanied by his book I Governor of California and how I ended poverty (1933)) which marked the closest attempt by a Socialist activist to achieve high office. Moreover, as there were over 700,000 unemployed workers in the state, Sinclair gained the approval of the disenfranchised population within California. The EPIC crusade's mass movement comprised of more than 2000 chapters, a vast voter registration campaign and a daily newspaper whose circulation achieved two million. For the state's businesses, the 
perception of having a Socialist as Governor elected by the dispossessed was tantamount to a social revolution. Within these circles, it was the press barons and the movie moguls who exercised their greatest disapproval of Sinclair. ${ }^{34}$

\section{Sinclair and the movie moguls}

Sinclair's problematic relations with Hollywood dated back to the early 1930s. Along with failed movie ventures including the backing of the Soviet director Sergei Eisenstein, he was offered $\$ 25,000$ by the industry pioneer William Fox in 1933 to write an expose on Hollywood's irregular financial practices --- Upton Sinclair presents William Fox (1933). This book damned the industry as being part of the illegitimate capitalist infrastructure through which 'the wires are pulled and strings (are) set. ${ }^{35}$ Further, Sinclair proposed to nationalise the film industry and impose strong federal regulations over the studios' dubious forms of accounting.

A year later, on the campaign trail Sinclair commented those film workers who had been laid off due to the 1933 downturn in production should be re-employed by the same companies which had let them go. He suggested unemployed actors and technicians might rent idle studios to produce free pictures of their own. For the moguls, this was a declaration of war and the call went out to 'stop Sinclair' (Sinclair, 1936: 190). Moreover, the Hollywood chiefs' intervention in the Sinclair campaign indicated a pivotal shift in their entrance into political affairs:

\footnotetext{
${ }^{34}$ Ceplair and Englund, The Inquisition in Hollywood, p. 90.

${ }^{35}$ Upton Sinclair, Upton Sinclair presents William Fox, (Los Angeles: Upton Sinclair, 1933), p xvi-xvii.
} 
It was the first campaign in which ... [the moguls] ... participated primarily to protect their economic interests. ... [Initially] the social attractions of politics --the desire to be embraced by powerful men ... overshadowed the economic ones. After the Sinclair campaign the two came into closer balance. For the moguls, the social rewards always remained strong. But from 1934 on, these needs were reinforced by economic necessity. ${ }^{36}$

\section{The propaganda campaign to stop Sinclair}

The moguls claimed if Sinclair was elected they would relocate their studios in Florida. For example, Columbia's Harry Cohn declared 'we will close our studios in a minute if [Sinclair] is elected. ${ }^{37}$ While this proved an idle threat, led by Louis Mayer and Irving Thalberg with the backing of Hearst who owned many movie theatres, they propagated an anti-Sinclair line in fake newsreels and supported the staid, incumbent Republican Governor Frank F. Merriam.

To mobilise opinion against Sinclair, the moguls and the Hearst controlled newspapers used anti-Communism as their principal weapon. Therefore, the Hearst papers declared Sinclair to be a 'most dangerous Bolshevik beast' who was trying to 'Russianize' California. Further, they staged a week-by-week attack on the campaign and in the first week instituted a news blackout on all EPIC activities. This was followed by a

\footnotetext{
${ }^{36}$ Brownstein, The Power and the Glitter, pp. 42-43.

${ }^{37}$ Greg Mitchell, The Campaign of the Century: Upton Sinclair's Race for Governor of California and the Birth of Media Politics, (New York: Random House. 1992) p. 199.
} 
ridicule Sinclair week, a Distort EPIC week, a Sidetrack Sinclair week, a Minimise Sinclair week and a Discredit Sinclair week. Throughout, EPIC 's message would be subjected to falsehoods. ${ }^{38}$

In tandem, MGM produced a series of California Election News newsreels to be shown in cinemas in the three weeks before the election. At the end of September 1934, Thalberg established a special film unit to produce these three movie shorts. This comprised from MGM screenwriter Carey Wilson, who had written the Hearst backed Gabriel over the White House in 1933, along with Felix Feist $\mathrm{Jr}$ (a test footage director) who shot the newsreels. ${ }^{39}$ In these shorts, authentic looking actors mixed with members of the public and were apparently 'interviewed' by the self-declared 'impartial inquiring cameraman' to raise concerns about the EPIC platform.

Thus, Merriam's supporters were presented as respectable members of the community who articulated the close relationship between economic prosperity and happiness. Conversely, Sinclair's supporters were itinerant lowlifes who declared they would flood California when the Socialist paradise was realised. For instance, in

\footnotetext{
${ }^{38}$ Mitchell, The Campaign of the Century, p. 118.

${ }^{39}$ Greg Mitchell 'A look inside Hollywood and the movies: Democracy in Action: How the Studios Torpedoed Upton Sinclair's Run for Office,' Los Angeles Times, October 31 1993. Accessed May 2 2013, http://articles.latimes.com/1993-10-31/entertainment/ca51476_1_upton-sinclair.
} 
Californian Election News No.3 trainloads of hobos and criminals were shown to be migrating to the state in lieu of the easy life promised to them by Sinclair. ${ }^{40}$

Thus, Thalberg skilfully played on Californian's fears of outsiders and state intervention over their freedoms. He employed realistic looking people to compare and contrast the 'differences' in the support between Merriam and Sinclair. Consequently, through these stereotypes it was obvious to whom middle-class Californians would direct their sympathies. While some EPIC supporters found these shorts to be so blatantly biased that they were comical in their distortions:

They were judging the short too much on what it said, not on what it showed. ... This was a new political medium --- a visual medium.... Forget the line of dialogue. It was the face --- the visual evidence --- that was important. ${ }^{41}$

The Merriam Tax: the involuntary contributions to the Merriam campaign imposed on the Hollywood workforce

Along with these propagandist newsreels, the moguls pressurised their employees to support Merriam and a fund a war-chest of $\$ 500,000$ which was deployed by Will Hays

${ }^{40}$ The Los Angeles Herald and Express published fake photo spreads of freight cars of tramps arriving in California on October 26 1934. Subsequently, it was shown that the stills were not news photos but shots taken from the Warner Brothers' feature Wild Boys of the Road (1933).

${ }^{41}$ Mitchell, The Campaign of the Century, p. 371. 
to 'stop' Sinclair. At first studio executives made their rank-and-file workforce listen to anti-Sinclair speeches made by prominent Republicans. Subsequently, each employee who made over $\$ 90$ a week was required to make a one-day contribution from their wages to stop Sinclair. In some studios employees were informed that they should donate a day's pay to the Merriam campaign funds. Elsewhere, they received a lighter pay check at the end of the week.

At Columbia the set department installed an enormous thermometer on the patio of the executive dining room. As the studio workers were forced to contribute to Merriam, the bar rose inexorably to the 100 per cent mark. Even the studio's top writing and directing team of Robert Riskin and Frank Capra, whose films celebrated idealism, courage and integrity, were made to contribute by Harry Cohn. Cohn, however, could not get two writers, the first President of the SWG John Howard Lawson and John Wexley (who were both Communists) to pay up. In the event, both refused to budge and Lawson, who was on a weekly contract, was fired. Wexley was more difficult to remove as he was on a long-term contract. He was suspended and lasted for six weeks when Cohn decided not to renew his option. ${ }^{42}$

At MGM studio workers received vouchers made out to Louis Mayer in place of their day's pay. Yet, the 'Merriam' tax led to a mini-mutiny amongst a group of solid MGM creative personnel. Sam Marx, the studio's story editor, immediately send monies to Sinclair. Others writers such as Frances Goodrich and Albert Hackett resisted the executive's pressure, and Allen Rivkin, on being told that if he worked for Sinclair he would be in trouble, promptly raised money at the studio to support EPIC. Similarly, at

\footnotetext{
${ }^{42}$ McGilligan and Buhle, Tender Comrades, p. 708.
} 
Warners, James Cagney wouldn't sign the studio's check to Merriam despite his alleged involvement in Hollywood's Communist uprising in 1933.

The moguls authoritarianism proved counter-productive as they inadvertently galvanised conservatives such as Morrie Riskind, moderates like Nunnally Johnson and left-wingers including Dorothy Parker to oppose their 'pleas' for money. They provided the fledgling SWG with a renewed sense of purpose when it passed a resolution condemning the threats they had used to canvass for monies. For instance, the young Billy Wilder as an émigré from Nazism found out he had no choice but to contribute $\$ 50$ to Merriam and was left with two conflicting thoughts:

One was: It may not be democratic, but it's a brilliant idea. Maybe if businessmen in Germany had deducted fifty marks from their workers to stop Hitler, Europe would be a safer place today. The other was: I fled fascism for THIS? ${ }^{43}$

\section{Hollywood supports EPIC}

The moguls' coercion led to outrage in the Hollywood community. The liberal actor Frederic March on discovering Thalberg had produced the fake newsreels castigated his boss at a cocktail party to which the Production Head replied 'Nothing is unfair in politics. ${ }^{44}$ Thalberg, who had been a Socialist orator as boy in the shadows of Tammany

\footnotetext{
${ }^{43}$ Mitchell, The Campaign of the Century, p. 360.

${ }^{44}$ Bob Thomas, Thalberg: Life and Legend, (New York: Doubleday, 1969), p. 269.
} 
Hall before embracing capitalism, continued, 'Fairness in an election is a contradiction in terms ... It just doesn't exist. ${ }^{45}$

Yet, the moguls' condescending attitude led to many workers deciding to support Sinclair. Therefore, stars such as Will Rogers, Jean Harlow, Chaplin and Cagney campaigned for EPIC, and writers including Parker and Riskind formed the Authors League for Sinclair. As Rivkin commented:

We rebelled, because we felt the man had the right to a fair campaign and that we had to speak for ourselves. It was democracy in action and a rebellion against the control of the studios over our non-studio lives. ${ }^{46}$

For many in Hollywood the Sinclair campaign marked a see-change in their political agendas and liberals such as Philip Dunne vowed revenge. Subsequently, Dunne and Melvyn Douglas established the MPDC and lined up to support the Democratic candidate Culbert Olson in the 1938 Californian gubernatorial election. Activists produced radio shows and film shorts, and displaying a keen wit, demanded Merriam should contribute one day of his salary to Olson's campaign funds. For politicians and newspaper editors, the film industry's activism betrayed its role as the purveyor of American fantasies and

\footnotetext{
${ }^{45}$ Mitchell, The Campaign of the Century, p. 561.

${ }^{46}$ Greg Mitchell, 'How Hollywood Fixed an Election', American Film (November 1988), p. 30.
} 
they subsequently produced headlines to smear 'red herrings across the gossamer gowns of Hollywood.' 47

\section{Merriam wins the election}

On the day before the election, the Hollywood trade papers informed their readers to:

\section{VOTE AGAINST UPTON SINCLAIR \\ CAST A VOTE TO SAVE YOUR JOB \\ VOTE TO SAVE THE MOTION PICTURE INDUSTRY. ${ }^{48}$}

Consequently, the power of the moguls and the Hearst press proved decisive as Sinclair only received 888,000 votes in comparison to the lacklustre Merriam's tally of $1,139,000$. Merriam praised his supporters within Hollywood, especially citing Louis Mayer, and the moguls congratulated themselves on securing Merriam’s victory over Sinclair. Mayer declared the Californian population had chosen patriotism over the evils of radicalism. Through their vilification of EPIC, they had shaped the media's coverage of the campaign and enforced their will on the Hollywood workforce. The moguls, with the Hearst papers, introduced many of the trends: polls, political advertising and public relation strategies, which would become commonplace in subsequent American elections. The Hollywood Reporter exclaimed that the campaign against Sinclair was dynamite as it

\footnotetext{
${ }^{47}$ Leo Rosten, Hollywood: The Movie Colony, The Movie Makers, (New York: Harcourt, Brace, 1941), p. 134.

${ }^{48}$ Shindler, Hollywood in Crisis, p. 65.
} 
was 'the most effective piece of political humdingery that has ever been effected!' ${ }^{49} \mathrm{~A}$ bitter Sinclair complained:

They [the moguls] have made propaganda and they have won a great victory with it, and are tremendously swelled up about it. You may be sure that never again will there be an election in California in which the great 'Louis Be' will not make his power felt ... California should stand up and sing hosannas for the greatest state industry, MOTION PICTURES, and the same industry should, for itself, point to its work whenever some ... scary legislation comes up in the various State Legislatures during the next few months. ${ }^{50}$

Ironically, the studios and the Hearst press were confronted by an increase in Corporation' taxes by the Merriam administration. Hearst was forced to close down several papers and the loyal moguls announced they would be leaving the state. For instance, Mayer went to see the Governor of North Carolina to negotiate a relocation of

\footnotetext{
49 The Hollywood Reporter cited from Arthur M. Schlesinger Jr., The Politics of Upheaval 1935-36, The Age of Roosevelt, Part 3, (Boston, New York: Houghton Miffin Company, 2003) p.119.

${ }^{50}$ Upton Sinclair, 'The Movies and political propaganda' in William J. Perlman, The Movies on Trial: The views and opinions of outstanding personalities and screen entertainment past and present, (New York: Macmillan Co., 1936), pp. 194-5.
} 
his studio. Once again they mobilised their forces to stem the tide of 'Socialism' associated with such taxes and lobbied to introduce a residency requirement for all those Californian's applying for welfare. Despite such pressure, they failed to convince Merriam to reduce taxes or to find more favourable conditions elsewhere. For the moguls, the Bolsheviks had managed to inveigle themselves into the Republican Party!

\section{$\underline{\text { Conclusion }}$}

Hollywood's politicization throughout the Depression reflected many of the trends which affected America in the interwar year period. Initially, the studio chiefs aligned themselves with the Republican Party. In part, this was due to its ideology as the party of business and as they wanted a minimal amount of governmental interference over their financial affairs. For Mayer, however, his affiliation with the GOP was driven by innate conservative ideologies and a desire to be accepted by the US elites.

This understanding reflected Hollywood's outsider status in mainstream US business and political affairs. For many WASPs, the film industry was treated with suspicion because of its Jewish complexion. The moguls sought to overcome such latent forms of anti-Semitism, thereby assimilating themselves into the elites who ran the country. This yearning for status determined their entry into politics and it went as far as Mayer perceiving himself to be a kingmaker for Hoover.

Yet, with the changes inaugurated by the New Deal Hollywood was characterised by a growing liberal sensibility. In contrast to their bosses, the industry's writers, directors and stars associated themselves with FDR's progressive reforms. They campaigned for Roosevelt, who understood the benefits of such celebrity endorsement. 
Moreover, many of these liberals were alarmed about the growth of Fascism in Europe and formed groups within the Popular Front. For a number of Hollywood activists this growing political consciousness led them to the Communist Party.

The division between the liberal and Communist factions of the Hollywood workforce became conspicuous in the fall-out surrounding the Stalin-Hitler pact. This created a bitter degree of acrimony which was profitably ploughed by the industry's reactionary forces. The 1938 Dies Committee marked the first major intervention of Congress concerning Hollywood's political affairs and, in spite of its failings, served as a warning to the industry. HUAC's anti-union stance would also establish divisions in Hollywood which were to reverberate in the anti-Communist witch-hunts that dominated the industry in the 1940s and 1950s.

Similarly, the differences between the management and workforce would simmer away under the surface throughout the 1920s and 1930s. These reached a head in Upton Sinclair's 1934 EPIC campaign when the moguls manipulated public opinion through bogus newsreels and demanded their employees should pay the 'Merriam' tax. The hardness of such 'mogul politics' was both effective and counter-productive. Although, Mayer and Thalberg led a successful campaign to determine the outcome of the election, their coercion galvanised the workforce into action and made apparent the divisions within the industry.

Therefore, Hollywood's status in political affairs demonstrated its growing importance as a purveyor of popular dreams throughout the interwar years. The moguls, liberals and radicals were united in their concerns about representing their contradictory values in the films they produced. Consequently, as there were reforms and retractions 
across the US's civic and social spheres, Hollywood became a significant force in reflecting and informing the societal debates which existed throughout American life. 